\title{
Effect of Animal Manure on the Incidence and Severity of Leaf Spot Disease of Fluted Pumpkin (Telfairia occidentalis) in Dschang, West Region of Cameroon
}

\author{
Mbong Grace Annih ${ }^{1}$, Nelomen Che Benedicte Tatiana ${ }^{1}$, Tonjock Rosemary Kinge ${ }^{2}$, \\ Anoumaa Mariette ${ }^{1}$, Andrew Kpu Kebei ${ }^{1}$ \\ ${ }^{1}$ Department of Plant Biology, Faculty of Science, University of Dschang, Dschang, Cameroon \\ ${ }^{2}$ Department of Biological Sciences, Faculty of Science, The University of Bamenda, Bamenda, Cameroon \\ Email: *gracembong@yahoo.com
}

How to cite this paper: Annih, M.G., Tatiana, N.C.B., Kinge, T.R., Mariette, A. and Kebei, A.K. (2020) Effect of Animal Manure on the Incidence and Severity of Leaf Spot Disease of Fluted Pumpkin (Telfairia occidentalis) in Dschang, West Region of Cameroon. American Journal of Plant Sciences, 11, 1057-1076.

https://doi.org/10.4236/ajps.2020.117076

Received: June 10, 2020

Accepted: July 17, 2020

Published: July 20, 2020

Copyright $\odot 2020$ by author(s) and Scientific Research Publishing Inc. This work is licensed under the Creative Commons Attribution International License (CC BY 4.0).

http://creativecommons.org/licenses/by/4.0/

\begin{abstract}
Fluted Pumpkin known as Telfairia occidentalis is an important vegetable crop in the tropics, cultivated for its leaf vegetable and edible seeds. It is a plant with a wide range of virtues but nevertheless; it is threatened by large scale fungal attacks. In order to manage the problem of food security and meet up with the production of this crop, this study was carried out to assess the effect of animal manure on the incidence and severity of leaf spot disease of Fluted Pumpkin and to determine the pathogenicity test of white leaf spot in Dschang. This research was done in the Faculty of Agronomy and Agricultural Sciences experimental farms at the University of Dschang from November 2017 to May 2018. The field layout was Randomized Complete Block Design with three treatments (poultry manure, piggery manure and control) and three replications. Each replicate consisted of six plots, giving a total of eighteen plots per treatment. In each treatment, fluted pumpkin was spaced at $1 \mathrm{~m} \times 1 \mathrm{~m}$ apart. Application of organic manure was done at 3 weeks after emergence and data collection were carried out weekly from 42 DAP. Pathogenicity test was conducted after the establishment of lesions on the leaves. Data were analyzed using descriptive and ANOVA. It was observed that piggery manure treatment had the highest disease incidence $(\mathrm{DI}=86.89)$ compared to the control $(\mathrm{DI}=85.42)$ and poultry manure $(\mathrm{DI}=65.74)$. The pathogenicity test revealed that Phoma sorghina was the causal agent for leaf spot disease in fluted pumpkin with a frequency of 18 . Disease incidence and severity was reduced in poultry manure, followed by the control with piggery manure having more disease. Therefore, poultry manure had a better man-
\end{abstract}


agement option of leaf spot disease on fluted pumpkins compared to the oth-

er treatments.

\section{Keywords}

Vegetable, Organic Fertilizer, Incidence, Severity, Pathogenicity

\section{Introduction}

Fluted Pumpkin (Telfairia occidentalis Hook F.) is an important vegetable crop in the tropics, cultivated for its leaf vegetable and edible seeds. It is a supine, creeping, vegetative shrub belonging to the Cucurbitaceae family [1]. Fluted Pumpkins develop long twisting tendrils that usually creep and spread on the surface of the ground if left unattended to and coiled through stakes [2]. It has an annual yield of $8.29 \mathrm{Mt} \cdot \mathrm{ha}^{-1}$ (leaves $5.52 \mathrm{Mt} \cdot \mathrm{ha}^{-1}$ and seeds $2.08 \mathrm{Mt} \cdot \mathrm{ha}^{-1}$ ) and harvesting takes place 120 - 150 days after sowing [3]. According to [3], it contains $39 \%$ crude protein, which is $9.5 \%, 18.11 \%$ and $8.2 \%$ higher than the available crude protein in Amaranthus sp., Talinum triangulate (Jacq.) and Solanum macrocarpon (L.) and also richer in iron. The oil obtained from fluted pumpkins is better for human consumption than palm oil because it has a lower saponification value and higher specific gravity [3]. The leaves contain vitamins and minerals needed by the body for its health [1]. They are locally used for cooking stews, soups, yam and vegetables, sauces and even for medicinal purposes such as in the treatment of malaria and typhoid amongst other illnesses [4] [5]. The leaves could be consumed in association with other foodstuffs like okra, dika nuts, egusi and others [6]. The large dark seeds (up to $5 \mathrm{~cm}$ ) are rich in fats and proteins, highly beneficial to human health and can be eaten whole, ground into powder for another kind of soup, or made into a fermented porridge [7]. The seeds are also potential raw materials for local industries, especially, in the Oleo chemical and animal feeds industries [8]. There has been an overwhelming increase in the consumption of fluted pumpkin leaves, seeds and shoots over the past years due to all the nutritive benefits obtainable from them [6].

Fluted Pumpkin is highly economic; thus its expansion and sales positively influence the economy of the rural population of Cameroon. In Cameroon, the harvested leaves are sold in bunch wrapped with plantains leaves and the price ranges from 200 to 1000 F CFA depending on the quantity (Personal Communication). This is especially in the Northwest and Southwest regions where its culture nowadays constitutes a major source of income. Nevertheless, little is known of the requirements for production of fluted pumpkin than for other food crops. Its production declined from 7.4\% to 3.4\% between 1994 and 1995 [3]. This is due to threats which include poor soil quality, hydric stress, low and high temperatures, insect invaders and diseases [2]. These diseases are more often fungal attacks and varying symptoms amongst which are generally: powdery 
mildew, soft rot, mottling, stunting and chlorosis. Of all the threats affecting Fluted Pumpkin, the most prominent one is leaf spot disease caused by Phoma sorghina. This species being the most common isolated is an opportunistic invasive phytopathogen which causes infection in animals and humans via consumption of contaminated food. The first proven infected human case was in 1956; it was a subcutaneous lesion in a post-renal transplant patient; next case was a young Canadian farmer with skin lesions on her lower extremity [9]. According to this same author, 32 cases of infection with age range from one month to 77 years old with three pediatric cases (9.4\%). 22 of the 32 cases (69\%) had skin injuries ranging from superficial to deep trauma. Five infections (16\%) were eye related and three cases $(9.4 \%)$ involved the lungs. This pathogen produces cytotoxic metabolites like tenuazonic acid which causes acute toxicity in humans such as precancerous changes in esophageal mucosa in mice [9]. More so, this disease is known to drastically reduce the market value and the storage duration of Fluted Pumpkin, on a scale ranging from 0 to 11 (that is from a state of no disease to that of very severe, which measure up to over $80 \%$ damage) [10]. It is on these bases that this study seeks to answer the question on how leaf spot disease and productivity of Fluted Pumpkin can be improved on.

Some study carried out on the diversity and production methods of fluted pumpkin by [2] reported that the major constraints of crop shoot production were the high cost of quality seeds and water pumps for watering since the growth of the plant depend on moisture content. Despite this study, little is known on leaf spot disease management and its production rate is still low where no proper attention is given to the growth of the crop. One of the ways productivity and market value could be improved is by managing diseases responsible for these reductions. According to [10], a lot of chemicals have been used in order to control the disease such as weekly foliar spraying with Dithane M-45 [2]. This control method renders productivity difficult and expensive for the poor farmers and is also not environmentally friendly. Thus, it becomes imperative to work out a strategy that is culturally based that could mitigate the effect of the disease at low cost. This study had as main objective to determine the effect of animal manure on the incidence and severity of leaf spot disease of Fluted Pumpkin (Telfairia occidentalis) in Dschang and carry out pathogenicity test of leaf spot disease on Fluted Pumpkin.

\section{Materials and Methods}

\subsection{Description of the Study Site}

The experiment for this study was conducted from the month of November 2017 to May 2018 in the Faculty of Agronomy and Agricultural Sciences (FASA) experimental farm at about $25 \mathrm{~m}$ from the main campus lake. This site is situated within the University of Dschang in Campus A (Figure 1). Dschang is located in the West Region of Cameroon between latitudes $5.27^{\circ} \mathrm{N}$ and $5.45^{\circ} \mathrm{N}$; longitudes $10.04^{\circ} \mathrm{E}$ and $10.067^{\circ} \mathrm{E}$. It is the capital of Menoua division, with the predominant 


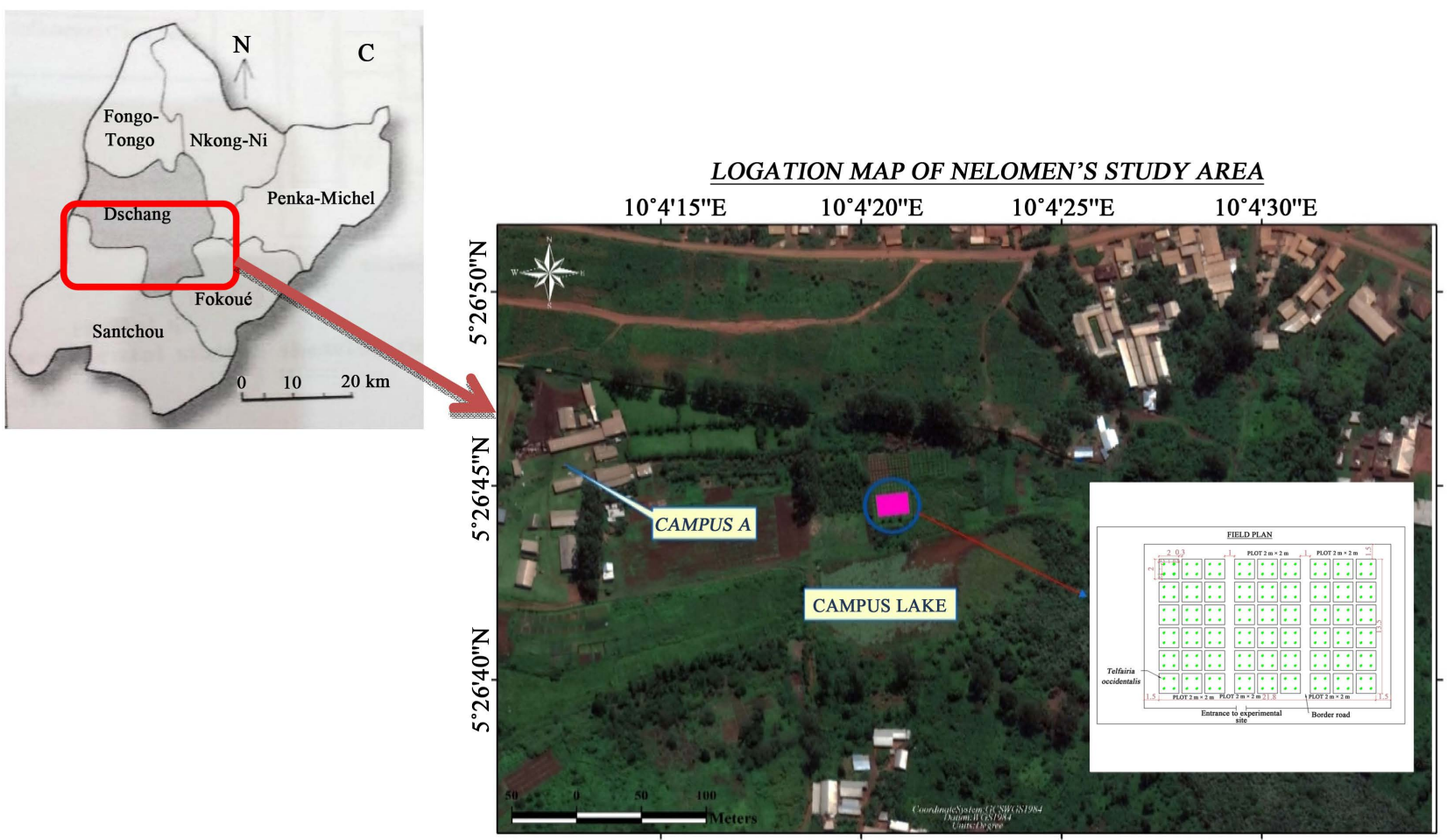

Figure 1. Map of the experimental site in the University of Dschang, West region of cameroon.

ethnic group being the Bamileke. This town is neighbored $46 \mathrm{~km}$ from Bafoussam (capital of the West Region), $54 \mathrm{~km}$ from Mbouda, and $26 \mathrm{~km}$ from the South West, $46 \mathrm{~km}$ from Melong and $84 \mathrm{~km}$ from Nkongsamba (Mungo). The experimental site was an open air field with a total area of $412.5 \mathrm{~m}^{2}(25 \mathrm{~m} \times 16.5$ $\mathrm{m})$.

\subsection{Source of Seeds and Substrate Used}

The seeds used for the experiment were fluted pumpkin seeds obtained from the Bamenda Food Market. The seeds used were freshly gotten from the fruits, dried for a few days in order to preserve its viability since the fluted pumpkin seeds are very recalcitrant (Figure 2). The substrates used for the experimental set up were top soils. Poultry manure obtained from poultry in Dschang and pig droppings obtained from a piggery in Mbouda due to its availability.

\subsection{Land Preparation and Establishment of the Crop}

In order to put in place a site for the research, a number of operation was carried out which started by clearing, ploughing and hallowing then ridging using cutlasses and rakes where the experiments was to be established. This was then followed by measuring the required surface area on which the experimental trails would be place in the disposition or the layout. Plots of $4 \mathrm{~m}^{2}$ were marked out with the use of a decameter, pegs and ropes. Fluted Pumpkins' seeds were then planted in November 2017 at a spacing distance of $1 \mathrm{~m} \times 1 \mathrm{~m}$, giving a total of 


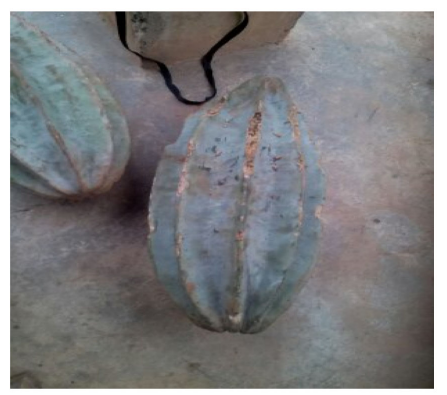

(a)

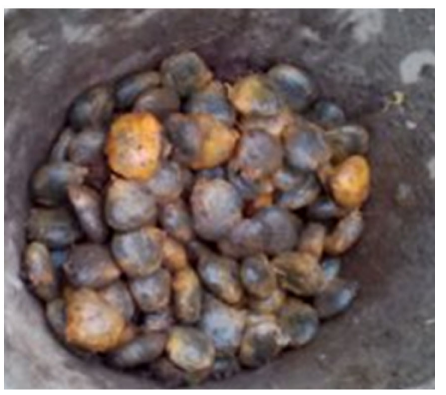

(b)

Figure 2. Plant materials used (a) Fluted Pumpkin fruits (b) Fluted Pumpkin seeds.

four plants per plot (216 Plants as total). Watering was done two to three times weekly with the aid of watering cans. The field lay out of this study was Randomized Complete Block Design (RCBD) with three treatments and three replications. Each replicate had six plots, giving a total of eighteen plots per treatment. Thus each treatment contained 18 plots $\left(4 \mathrm{~m}^{2}\right.$ each) and each of the 18 plots had four plants of fluted pumpkin spaced one meter apart. Each plot was separated from the next by a $30 \mathrm{~cm}$ between plots of the same treatment and $1 \mathrm{~m}$ border row. The field layout is shown in Figure 3.

\subsection{Application of Substrates and Management Practices}

Organic substrate (poultry manure and pig droppings) was chosen over inorganic fertilizers with respect to certain characteristic which surpasses their inconveniencies. Despite the bulky and cumbersome nature of these manures; they possess potentials such as good organic matter content; porosity; water retention capacity and density; their slow degradation and release of nutrients according to the needs of the plant; their capacity to reconstitute humus and not forgetting their environmental friendliness. Incorporation of the two forms of organic manure (poultry and piggery manures), of $5 \mathrm{t} / \mathrm{ha}$ of each type was done three weeks after emergence of seedlings. A bamboo fence was built in order to prevent the intrusion of vandals and uncontrolled animals within the campus and disruption of the experiment. This was carried out simultaneously alongside the preparation of the experimental field; it took a couple of weeks. Weeds were being controlled manually and subsequently by hand pulling as the fluted pumpkins vines spread and covered the plots to thus suppress weed growth. Trellis was built to stake the fluted pumpkins plants for easy spreading and expansion of the plant.

\subsection{Data Collection}

After planting, observations were made on daily bases for any noticeable change like appearance of white spots on the plants. The plants were subsequently monitored in the field and changes were noted and recorded. The parameters used for disease incidence in the field to determine disease characteristics consisted of counting and recording the number of infected leaves per plant, number of 


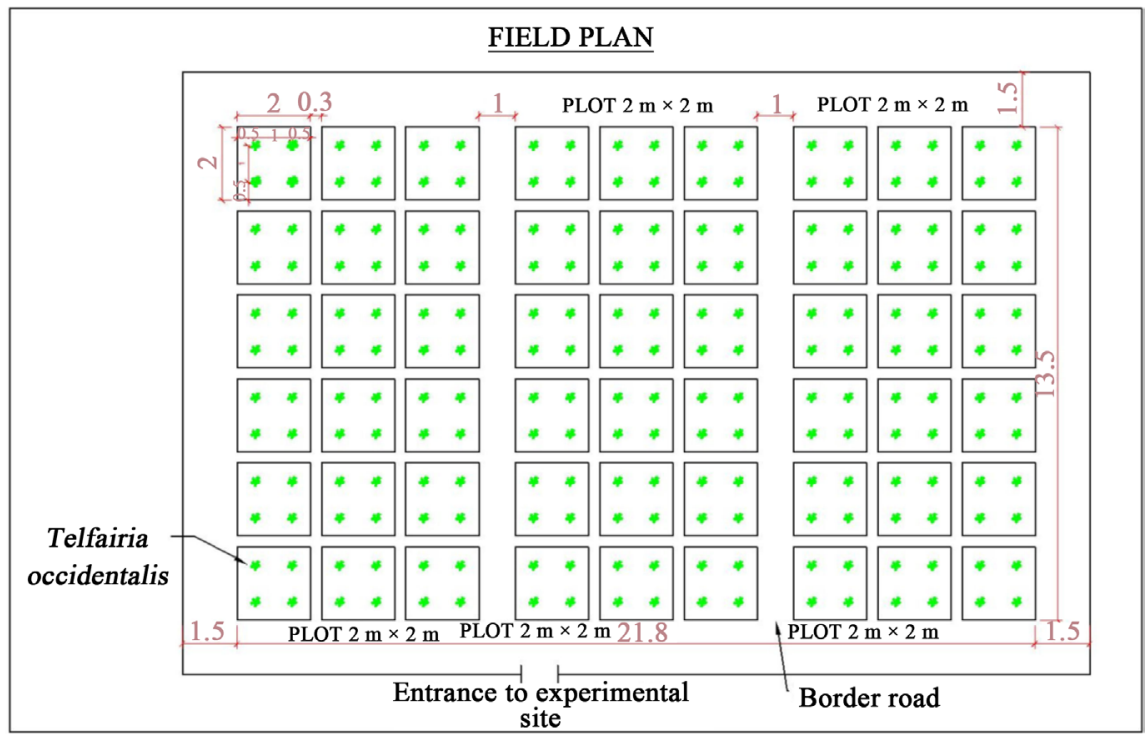

Figure 3. Field layout and distribution of $T$. occidentalis plants.

infected leaflets per leaf and the number of infected plants per treatment. Data were collected on all the plants in the field. The method of observation used was by visual assessment beginning from first appearance of the symptoms on the fluted pumpkin plants. Data were scored on weekly intervals, and recording was done in Days After Planting (DAP) of seeds. The stand count was also taken into consideration.

\subsection{Evaluation of Leaf Spot Disease Incidence (DI) on Fluted Pumpkins}

Data on the incidence of leaf spot disease on fluted pumpkin was collected at weekly interval on all the emerged plants in the field. It was done from 42 DAP of seedlings. The incidence was calculated as follows:

$$
\% \text { Disease incidence }(\mathrm{DI})=\frac{\text { number of leaves infected }}{\text { total number of leaves sampled }} \times 100
$$

\subsection{Evaluation of Leaf Spot Disease Severity (DS) on Fluted Pumpkins}

Disease severity was scored at 7 days intervals using a scale of Horsfall \& Barratt [11] modified (Table 1).

\subsection{Pathogenicity Test on Causal Agent of Leaf Spot Disease of T. occidentalis}

To confirm the identity of the pathogen, Koch's postulate was followed. The culture and isolation of the pathogenic agent were realized in the phytopathology laboratory in the University of Dschang as well as the pathogenicity test. This began from identification of infected plants, isolation of fungus, purification, identification, and inoculation. 
Table 1. Disease severity scale modified.

\begin{tabular}{ccl}
\hline Index & $\begin{array}{c}\text { Percent } \\
\text { Affected }\end{array}$ & \\
\hline 0 & $0 \%$ & No disease infection \\
1 & $5 \%-15 \%$ & Few lesions of leaf spot disease infection dotted on fewer leaflets \\
2 & $15 \%-25 \%$ & Moderate lesions of leaf spot infection on fewer leaflet \\
3 & $25 \%-50 \%$ & Leaf spot infection on at least half of the fluted pumpkin plants \\
4 & $50 \%-75 \%$ & Leaf spot disease on the surface of the leaflets and showing holes \\
5 & $75 \%-85 \%$ & Leaf spot infection on almost all the leaflets with spots coalescing \\
6 & Above 85\% & About 90\% of the leaflets showing leaf spot disease with leaves tearing off \\
\hline
\end{tabular}

\subsubsection{Preparation of Potato Dextrose Agar (PDA) Culture Medium}

200 grams of Solanum tuberosum was washed, peeled, sliced and boiled in 500 $\mathrm{ml}$ of distilled water for 20 minutes for juice extraction. They were then filtered through cheesecloth, saving effluent, which is potato infusion. The obtained juice was mixed with 14 grams agar (for medium solidification), 10 grams dextrose (D-glucose-a sugar), 6 capsules ( 1 capsule $\times 250 \mathrm{mg}$ ) of chloramphenicol (antibiotics which prevent the development of bacteria) and $1000 \mathrm{ml}$ of water and boiled to dissolve. This mixture was later homogenized and kept in the autoclave for 15 minutes at $121^{\circ} \mathrm{C}$ for disinfection. It was then dispensed $20-25 \mathrm{ml}$ portions into previously sterilized $90 \mathrm{~mm}$ diameter petri dishes in an oven at $140^{\circ} \mathrm{C}$ for 120 minutes.

\subsubsection{Determination of Pathogenicity Test of Leaf Spot Disease on Fluted Pumpkins}

The infected fluted pumpkin leaves were harvested from diseased plants (showing abnormalities) in the field. This was done with the aid of a sterilized razor blade and placed in labeled polythene bags, then carried to the Phytopathology Laboratory of the University of Dschang where culture, isolation and identification of the causal agent was done. These leaves were rinsed under a flowing tap in the laboratory and thereafter cut into about $2 \mathrm{~mm}^{2}$ sections at the interface between the infected and healthy portions with a sterilized blade. Cut leaf sections were surface sterilized with $5 \%$ sodium hypochlorite $\left(\mathrm{NaOCl}_{3}\right)$ solution for $5 \mathrm{~min}$ and immediately rinsed in three changes of sterilized distilled water for 5 minutes, 10 minutes, and 15 minutes respectively, in order to suppress the traces of the disinfectant. It was then dried on filter papers. Five leaf pieces were aseptically placed at equidistance's in each Petri dish of $90 \mathrm{~mm}$ in diameter containing 20 - $25 \mathrm{ml}$ of PDA in the hood beside a Bunsen beck to avoid contamination. Inoculated plates were incubated at $18^{\circ} \mathrm{C} \pm 2^{\circ} \mathrm{C}$ until fungal growth was noticed. After 5 days, the different isolates were sub-cultured into freshly prepared PDA plates to obtain and maintain pure cultures of the fungi.

\subsubsection{Pathogen Identification}

Isolated fungi were identified as far as possible based on the morphological cha- 
racteristics of the mycelium, as for the presence or absence of septa and organs of fructification (conidia) were observed under the microscope $(\times 400)$. This identification was concretized with the used of identification guides of the International Mycological Institute Kew and that of [12].

\subsubsection{Artificial Culture of Fungal Isolates}

In order to confirm whether the pathogens isolated from pure culture could produce symptoms of the disease as observed on the field, suspensions of all pure culture isolates were prepared under aseptic conditions with distilled water. A drop of Twin 20 solution was added to each plate to homogenize the suspension. Conidial suspensions obtained were filtered through a double layer of filter paper to remove leaf debris. The pure cultures obtained were then sealed in Petri dishes with the aid of Para film and conserved at temperatures between $18^{\circ} \mathrm{C}$ $20^{\circ} \mathrm{C}$. Apparently healthy and fresh fluted pumpkin leaves were harvested with the aid of a knife from each from each treatment and taken to the laboratory.

\subsubsection{Preparation of Inoculum and Inoculation of Healthy Plants}

The inoculum was prepared from pure cultures of different fungal strains 5 days after its pure culture. The spore suspension was obtained by brushing the pure culture of each fungus with $20 \mathrm{ml}$ of sterilized distilled water with a fine brush. Filtration was later done to eliminate mycelia fragments. These suspensions were preserved in clean penicillin bottles awaiting inoculation.

A total of twenty one (21) healthy leaves were detached from plants and carried to the phytopathology laboratory of the University of Dschang and washed with flowing tap water. The surface was sterilized by swabbing with hypochlorite solution at $5 \%$ for two minutes, and then rinsed with distilled water for five minutes. Inoculation was done with blended mycelia suspension of the fungus. These leaves were inoculated with $50 \mu \mathrm{L}$ of inoculum with the aid of a micropipette and then placed in sterile Petri dishes containing cotton wool moistened with sterilized distill water and incubated at ambient temperature for 7 days. This inoculation was done at $23^{\circ} \mathrm{C}$ with an alternation of 12 hours of daylight and 12 hours of darkness. Developing lesions were compared with those observed in the field.

\subsection{Statistical Analysis}

All data collected on disease incidence, severity on the leaves, infected plants, and leaflets were input into EXCEL 2010 and XLSTAT 2017 was used to run Analysis of Variance (ANOVA) and the treatment means were separated using Duncan Multiple Range Test (DMRT) for statistical significant at 95\% confident interval $(\mathrm{P} \leq 0.05)$.

\subsection{Evaluation of Germination of Three Treatments of T. occidentalis}

Germination proportion was assessed looking at the survival rate of the fluted pumpkin and this was done using the formula below: 


$$
\% \text { Germination }=\frac{\text { number of plants germinated }}{\text { total number of seeds planted }} \times 100
$$

\section{Results}

\subsection{Determination of Disease Incidence and the Mean Disease Severity on the Number of Infected Leaves per Plant of Fluted Pumpkin at Different DAP and Treatments}

The disease incidence was determined by the first appearance of the white spot disease on the leaves per plant of fluted pumpkin. This was characterized by the expression of the white rust disease, which was easily identified with the naked eyes. This disease was assessed at weekly interval starting from 42 DAP to 63 DAP. The disease expression varied with the plants and with time. Figure 4 showed the incidence of leaf spots disease on the leaves of fluted pumpkin as recorded at weekly interval per treatments. The disease incidence was lower with the applications of poultry manure at $42 \mathrm{DAP}, 49 \mathrm{DAP}, 56 \mathrm{DAP}$ and $63 \mathrm{DAP}$ respectively. There was a progressive increase in disease incidence with the application of piggery manure at $49 \mathrm{DAP}, 56 \mathrm{DAP}$ and $63 \mathrm{DAP}$ respectively, with 63 DAP recording the highest disease incidence on the number of leaves per plant of fluted pumpkin. There was no difference in disease incidence on the number of leaves per plant on the control treatment at 42 DAP and 49 DAP respectively, but a progressive increased was observed at 56 DAP and 63 DAP respectively (Figure 4).

Looking at the mean disease severity of white spot disease on the number of leaves per plant of fluted pumpkin, it was observed that there was no significant difference in mean disease severity on the number of leaves per plant in all the treatments at $42 \mathrm{DAP}$ (Table 2). At $49 \mathrm{DAP}$, a significant $(\mathrm{P} \leq 0.05)$ difference was observed in the mean disease severity of white spot disease on the number of leaves per plant of fluted pumpkin having application of piggery manure compared with the control and poultry manure treatments at 56 DAP and 63 DAP respectively. At $49 \mathrm{DAP}$, poultry manure showed the least disease severity on the number of white spot disease on the number of leaves per plant compared to all

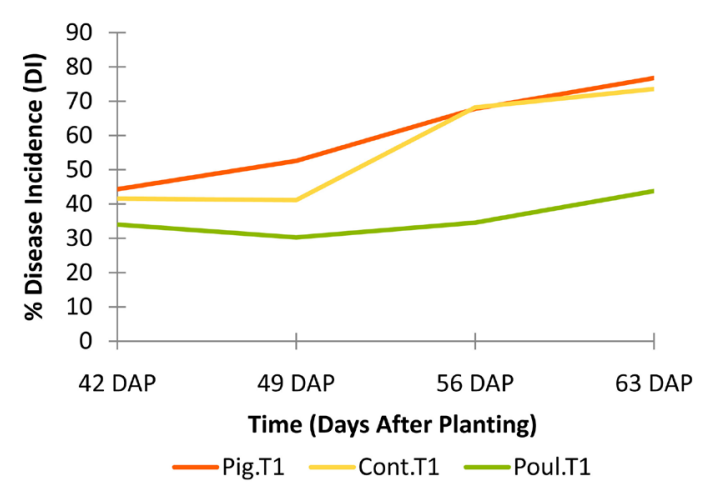

Figure 4. Evolution of disease incidence on the number leaves infected per plant of fluted at different DAP and across treatments (Pig.T1 = Piggery manure; Cont.T1 = Control; Poul.T1 = Poultry manure). 
Table 2. Disease severity on the number of leaves infected per plant of fluted pumpkin at different DAP and treatments.

\begin{tabular}{ccccc}
\hline Treatments & 42 DAP & 49 DAP & 56 DAP & 63 DAP \\
\hline Pig.T1 & $44.33 \pm 29.82 \mathrm{a}$ & $52.60 \pm 28.95 \mathrm{a}$ & $67.78 \pm 15.73 \mathrm{a}$ & $76.75 \pm 17.48 \mathrm{a}$ \\
Cont.T1 & $41.62 \pm 22.27 \mathrm{a}$ & $41.17 \pm 28.95 \mathrm{ab}$ & $68.21 \pm 15.10 \mathrm{a}$ & $73.58 \pm 19.17 \mathrm{a}$ \\
Poul.T1 & $34.06 \pm 22.27 \mathrm{a}$ & $30.28 \pm 27.29 \mathrm{~b}$ & $34.60 \pm 23.97 \mathrm{~b}$ & $43.81 \pm 29.05 \mathrm{~b}$ \\
\hline
\end{tabular}

Value in a column for each treatment followed by the same letters is not significantly different at $\mathrm{P} \leq 0.05$ (DMRT)

the treatments. The trend of mean disease severity of white spot disease on the number of leaves at $56 \mathrm{DAP}$ and $63 \mathrm{DAP}$ was the same with a significant ( $\mathrm{P} \leq$ $0.05)$ difference observed with piggery manure and control compared with application of poultry manure that showed the least mean disease severity of white spot disease on fluted pumpkin (Table 2).

\subsection{Determination of Disease Incidence and the Mean Disease Severity on the Number of Infected Leaflets per Plant of Fluted Pumpkin at Different DAP and Treatments}

The assessment of the disease incidence of white leaf spot diseases on the number of infected leaflets per plant of fluted pumpkin was recorded at weekly interval per treatments. Figure 5 showed that the disease incidence on the number of infected leaflets per plant of fluted pumpkin infected by white leaf spot disease was lower with the applications of poultry manure at $42 \mathrm{DAP}, 49 \mathrm{DAP}, 56 \mathrm{DAP}$ and 63 DAP respectively. Comparing the application of piggery manure on fluted pumpkin with the control treatment, it was observed that the two treatments showed a progressive increase in disease incidence on the number of infected leaflets per plant with white spot disease from 49 DAP. But the disease incidence on the number of infected leaflets per plant in the control treatment was higher at 56 DAP compared with the application of piggery manure. At 63 DAP, the disease incidence on the number infected leaflets per plant of fluted pumpkin with white spot disease was higher at 63 DAP compared to all the treatments (Figure 5).

With regards to the mean disease severity of white spot disease on the number of infected leaflets per plant of fluted pumpkin across the different treatments, a significant difference was observed in all the days after planting. In comparing the different treatments, it was observed that at 42 DAP and 49 DAP there was no difference in the mean disease severity in the number of infected leaflets per plant in the control treatment and the application of piggery manure. This was the same for the applications of poultry manure at 42 DAP and 49 DAP. But poultry manure had a lower mean disease severity of white spot disease on the number of infected leaflets per plant with white spot disease at 42 DAP and 49 $\mathrm{DAP}$ compared to the other treatments. At $56 \mathrm{DAP}$, a significant $(\mathrm{P} \leq 0.05)$ difference was observed in the mean disease severity with the three treatments, with 


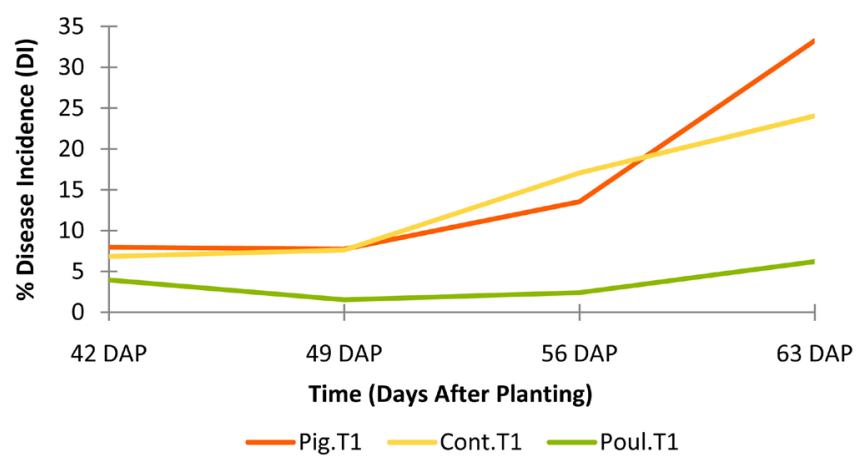

Figure 5. Evolution of disease incidence on the number of infected leaflets per plant of fluted pumpkin at different DAP and across treatments (Pig.T1 = Piggery manure treatment, Cont.T1 $=$ Control and Poul.T1 $=$ Poultry manure treatment).

the control treatment having a higher mean disease severity, followed by piggery manure, with poultry manure treatment having the least disease severity. At 63 DAP a reverse in significant difference was observed with piggery manure and the control treatment, with piggery manure having a higher mean disease severity, followed by control treatment, the poultry manure treatment had the least disease severity (Table 3).

\subsection{Determination of Disease Incidence and the Mean Disease Severity on the Number of Plants of Fluted Pumpkin Infected with White Spot Disease at Different DAP and Treatments}

Considering the disease incidence of the leaf spot disease on the number of plants of fluted pumpkin infected, it was observed that the three treatments showed some variation in the rate of infection with respect to the four different planting dates. Piggery manure had the highest white spot disease incidence on the number of plants infected at $42 \mathrm{DAP}$, followed by the control treatment and lastly the foul manure treatment that showed the least disease incidence (Figure 6). There was no difference in the disease incidence of white spot disease on the number of plants of fluted pumpkin with the application of piggery manure and the control treatments at 49 DAP, 56 DAP and 63 DAP. But at 49 DAP, 56 DAP and 63 DAP, fluted pumpkin with application of foul manure showed the least disease incidence on the number of plant infected with white leaf spot disease (Figure 6).

The assessment of the mean disease severity of white spot disease on the number of plants of fluted pumpkin infected revealed that there was a progressive increase in disease with respect to the different treatments and different planting dates. Comparing the control treatment and the application of piggery manure on fluted pumpkin, it was observed that both treatments showed that there was no difference in disease severity with respect to all the planting dates used in this study but a significant $(\mathrm{P} \leq 0.05)$ was observed with the application of poultry manure treatment for all the planting dates compared to the control and piggery manure treatments respectively (Table 4). 


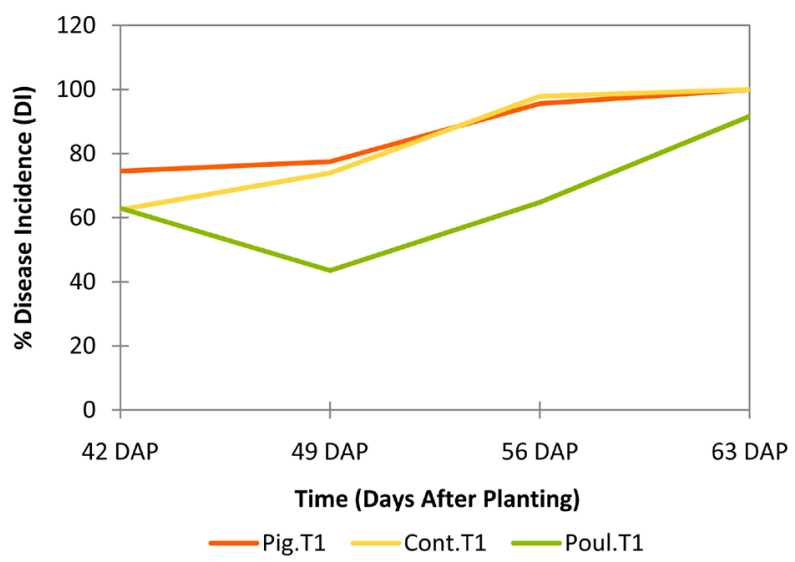

Figure 6. Evolution of incidence in the number of plants of fluted pumpkin infected with white spot disease at different DAP and treatments.

Table 3. Disease severity on the number of infected leaflets per plant of fluted pumpkin showing white spot disease at different DAP and treatments.

\begin{tabular}{ccccc}
\hline Treatments & 42 DAP & 49 DAP & 56 DAP & 63 DAP \\
\hline Pig.T1 & $7.97 \pm 5.94 \mathrm{a}$ & $7.75 \pm 5.55 \mathrm{a}$ & $13.55 \pm 8.28 \mathrm{~b}$ & $33.27 \pm 10.29 \mathrm{a}$ \\
Cont.T1 & $6.83 \pm 5.68 \mathrm{a}$ & $7.61 \pm 5.99 \mathrm{a}$ & $17.07 \pm 7.13 \mathrm{a}$ & $24.05 \pm 7.29 \mathrm{~b}$ \\
Poul.T1 & $3.96 \pm 3.21 \mathrm{~b}$ & $1.54 \pm 1.74 \mathrm{~b}$ & $2.41 \pm 2.01 \mathrm{c}$ & $6.21 \pm 3.60 \mathrm{c}$ \\
\hline
\end{tabular}

Value in a column for each treatment followed by the same letters is not significantly different at $\mathrm{P} \leq 0.05$ (DMRT)

Table 4. Mean disease severity on the number of plant of infected fluted pumpkin showing white spot disease at different DAP and treatments.

\begin{tabular}{ccccc}
\hline Treatments & 42 DAP & 49 DAP & 56 DAP & 63 DAP \\
\hline Cont.T1 & $0.12 \pm 1.50 \mathrm{a}$ & $2.28 \pm 1.32 \mathrm{a}$ & $3.81 \pm 0.63 \mathrm{a}$ & $4.92 \pm 0.57 \mathrm{a}$ \\
Pig.T1 & $2.15 \pm 1.39 \mathrm{a}$ & $2.15 \pm 1.34 \mathrm{a}$ & $3.37 \pm 1.05 \mathrm{a}$ & $5.32 \pm 0.81 \mathrm{a}$ \\
Poul.T1 & $1.45 \pm 1.16 \mathrm{~b}$ & $1.06 \pm 0.76 \mathrm{~b}$ & $2.42 \pm 0.81 \mathrm{~b}$ & $3.340 \pm 1.04 \mathrm{~b}$ \\
\hline
\end{tabular}

Value in a column for each treatment followed by the same letters is not significantly different at $\mathrm{P} \leq 0.05$ (DMRT).

\subsection{Different Pathogens Associated with Pathogenicity Test on Fluted Pumpkins}

White leaf spot disease was the disease observed in the field caused by certain groups of fungi. A variety of fungi belonging to six different genera and species responsible for the leaf spot disease that were isolated from the pure cultures were the same fungi that were again isolated from the artificial cultures (Figures 7-12). These include Phoma sp. (this was more prominent), Aspergillus niger, Penicillium sp., Fusarium oxysporum, Trichoderma viridi, and Cercospora sp.

\subsection{Frequency of Pathogens Isolated}

Six different pathogenic fungi, of different genera and species were isolated from pure cultures from fluted pumpkin leaves harvested from the field. According to 


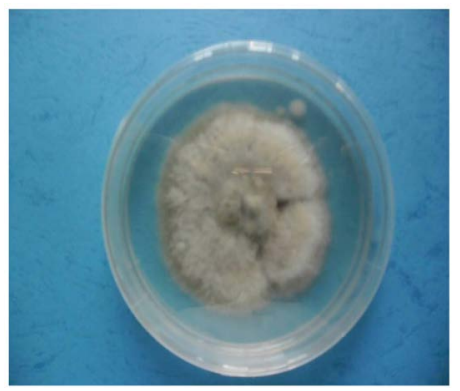

(a)

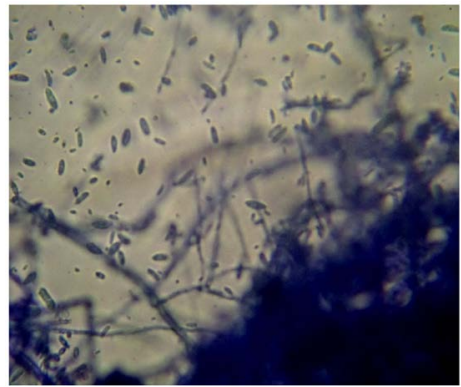

(b)

Figure 7. Showing Phoma sp. (a) Pure culture (b) mycelia and conidia $(\times 400)$.

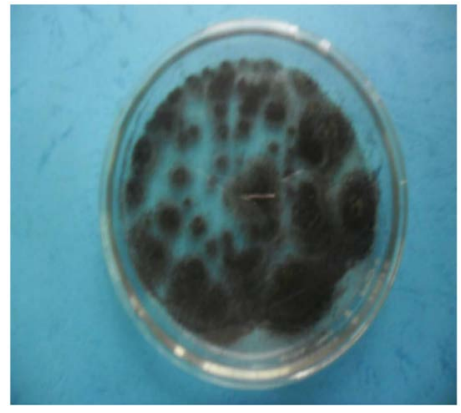

(a)

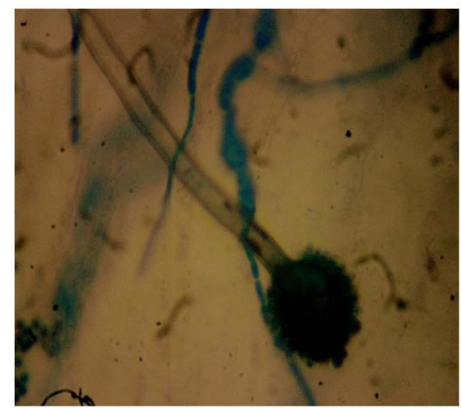

(b)

Figure 8. Showing Aspergillus niger (a) Pure culture (b) mycelia and conidia $(\times 400)$.

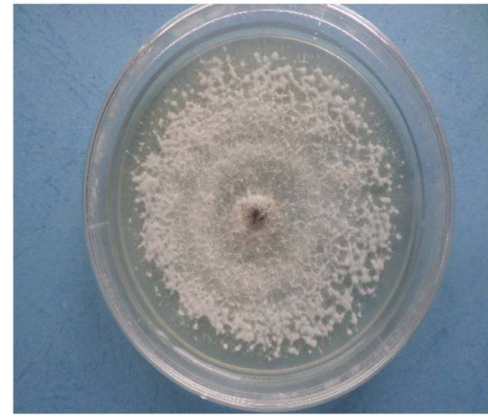

(a)

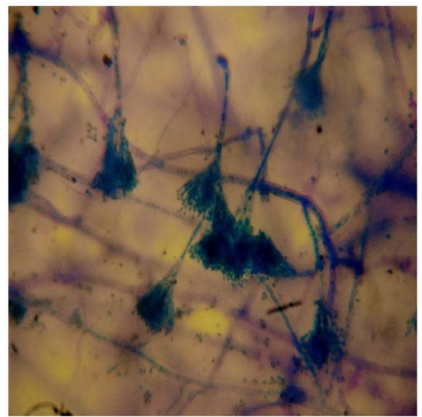

(b)

Figure 9. Showing Penicillium sp. (a) Pure culture (b) mycelia and conidia $(\times 400)$.

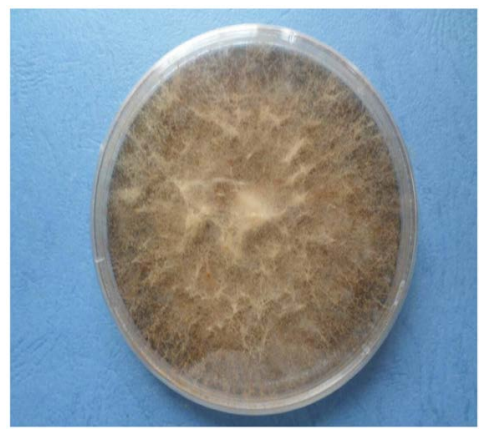

(a)

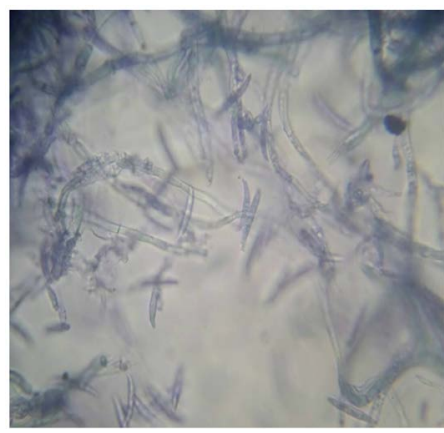

(b)

Figure 10. Showing Fusarium oxysporum (a) Pure culture (b) mycelia and conidia $(\times 400)$. 
the number of pieces of leaves representing each pathogen, different frequencies were obtained for each culture. Phoma $s p$. was isolated as the main pathogen responsible for leaf spot disease in the field with frequencies of respective 18, followed by Fusarium oxysporum and Cercospora sp. with respective frequencies of 14 and 11 respectively; and lastly Penicillium sp. and Aspergillusniger with both frequencies of 3. Tricoderma $s p$. was not isolated to have a representative pathogen frequency (Figure 13).

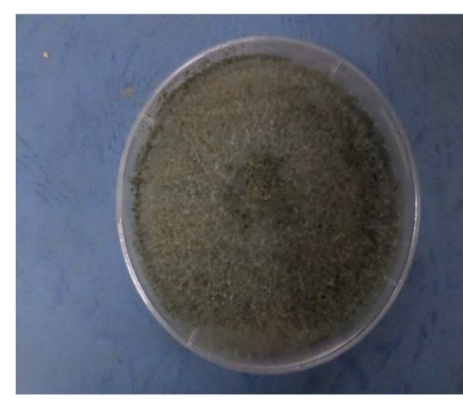

(a)

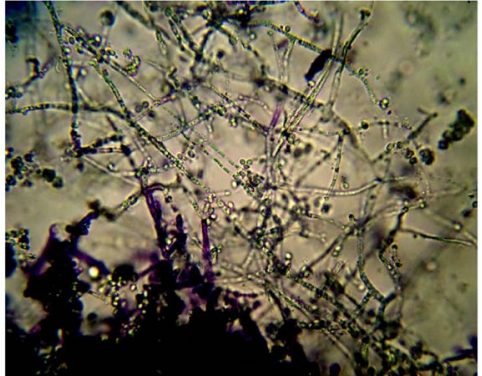

(b)

Figure 11. Showing Trichoderma viridi (a) Pure culture (b) mycelia and conidia $(\times 400)$.

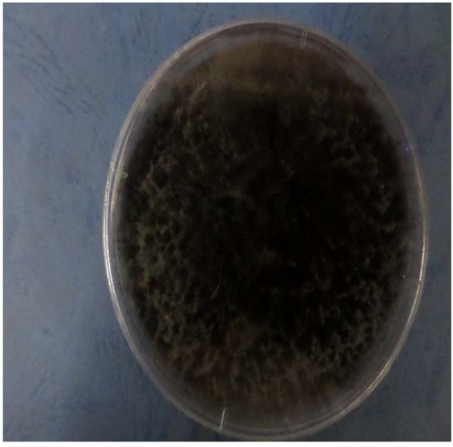

(a)

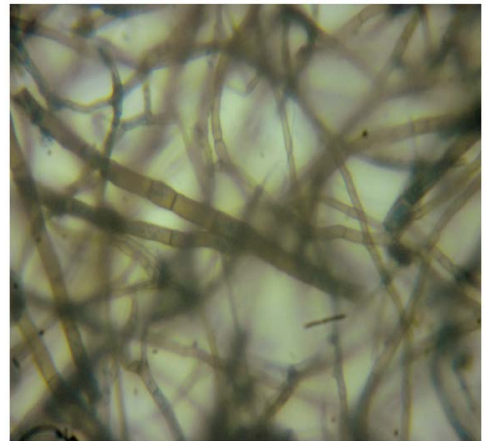

(b)

Figure 12. Showing Cercospora sp. (a) Pure culture (b) Mycelia $(\times 400)$.

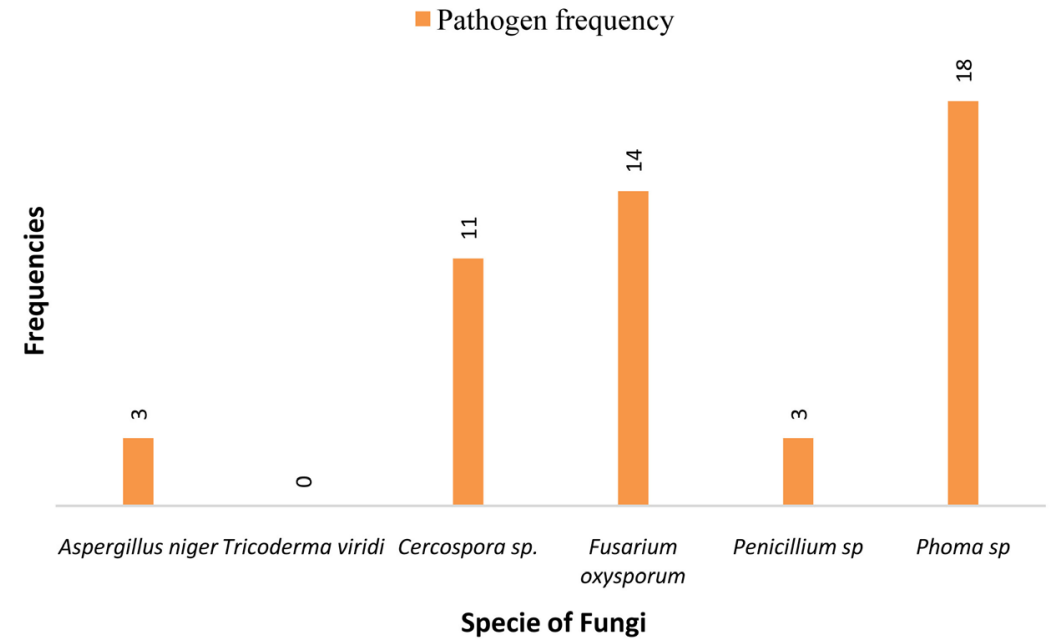

Figure 13. Frequencies of fungi species isolated from pure culture. 


\subsection{Description of Fungi Pathogens Isolated and Identified on Fluted Pumpkin Plants}

The six species of fungi isolated and identified on fluted pumpkin. The six species are: Phoma sorghina (Dothideomycetes); Aspergillus niger (Sordariomycetes); Penicillium sp. (Eurotiomycetes); Fusarium oxysporum (Sordariomycetes); Trichodema viridis (Sordariomycetes); Cercospora sp. (Dothideomycetes). Phoma sorghina in pure culture presented hyaline or white, colourless and thick spores. They also produced thick septate mycelia with many pycnidia. The pycnidia are black, regular and glabrous. Conidia are ellipsoidal to cylindrical, thin-walled, smooth hyaline and aseptate. Aspergillus niger in pure culture presented a black mycelial colony. Microscopic Observations revealed that its conidiophores were erect and swollen at the extreme to form a spherical or ovoid head. The spores were formed from sterigmata into very long chains. The spores under culture were nevertheless darkish and were globular to ovoid in shape. Penicillium $s p$. appeared to have branched conidiophores, round and unicellular conidia. They also had small, branched network of multinucleated, septate and colourless hyphae. Fusariumoxysporum, initially showed whitish mycelia which became brownish with age. The conidiophores were short, single, and had flask-shaped projections in the aerial mycelium, which later became clusters. The macroconidia were fusiform, abundant, never in chains, and mostly non-septate and cylindrical. The chlamydospores were terminal, hyaline and smooth. This fungus was characterized by globose conidia. Its hyphae were gray in colour and the species produced more prolific spores. Cercospora $s p$. in pure culture presented a grayish mycelium with a cotton texture. Under the microscope, it was observed that the fungus possessed mycelia which were relatively short; compacted and had elongated conidiophores which were fasciculate.

\subsection{Confirmation of Causal Pathogen}

The fungi that were re-isolated from pure cultures were similar to those isolated from the infected fluted pumpkin leaves harvested from the field. The fungi were also seen to cause symptoms of the disease (white leaf spot) as that observed on the experimental field. The total number of spots (severity of the each pathogen) on the three leaflets inoculated for the same pathogen however was counted. Phoma sp. was said to produce the highest number of spots, which implies that it was the most virulent leaf spot pathogen on the leaflets with 227 leaf spots; this was closely followed by Cercospora sp. with 199 leaf spots; while the other pathogens had leaf spot disease ranging from 17 - 45. Aspergillus niger produced the least number of spots (17) on the leaves of fluted pumpkin (Figure 14).

\section{Discussion}

Generally, there was no great difference between the mean disease incidence and severity for the first and second week of collection (42 and 49 DAP respectively) in the control treatment. This could be due to the slow release of nutrients by the by the different fertilizers. This was in line with results obtained by [13] who 


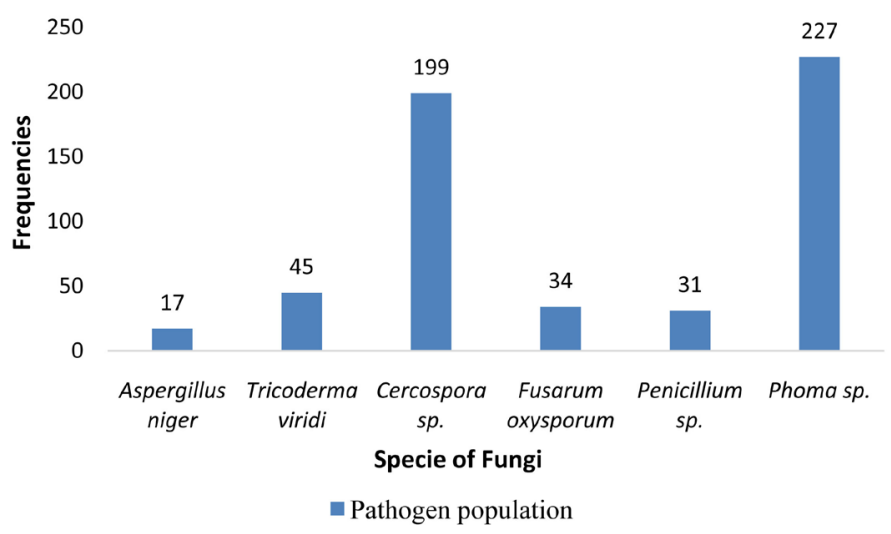

Figure 14. Number of spots produced by fungi on leaves in artificial culture.

reported that over a period of 140 days the nutrient released by organic fertilizer is between $26 \%$ and $60 \%$ (nitrogen content) which is contrarily to the nutrient release of inorganic fertilizer which contains nearly all the nitrogen content. The results obtained from this study revealed that leaf spot disease of fluted pumpkin could be managed when the plants are treated with poultry manure. The effect of poultry manure on the management of leaf spot disease of fluted pumpkin could be attributed to the different variations in the composition of the poultry manure from the different ages of the birds, its feed ratio and handling systems, which could lead to a high composition in potassium, nitrogen and phosphorus (NPK) including some trace elements. These different elements found in foul dung could induce resistance to the pathogens that cause leaf spot disease infection. This assumption is in line with the findings of Ihejiri et al. [14] who noted that nutrient absorption by plants facilitates normal physiological function and photosynthetic processes of these plants for proper built up. The poultry manure when properly dried avoids plants from undergoing stress and pathogen infection since these pathogens require some moist conditions for their growth. This condition could be harmful to the plants by distorting their growth and also to the end users of these plants [15]. The low incidence in leaf spot disease recorded on fluted pumpkin treated with poultry manure in this study was in line with the results obtained by [16] who reported that treatment of leaf curl disease on two varieties of pepper in Nigeria with poultry manure reduced the disease incidence and severity the disease considerably thus increasing yield and quality of the pepper fruits. Also, the low disease incidence and severity in plants treated with poultry manure could be attributed to its very high nutritive elements which is additive. This declaration supports the findings of [17] who stated that antibiotics are a common additive to poultry diet, which induced plant resistance to pathogen thus making them to record lesser disease incidence and severity comparatively. Poultry manure upon decomposition releases nitrogen contents and allele chemicals leading to a decrease in pathogen population. Similar claims were reported by [18].

Piggery manure treatments recorded a high disease incidence and severity than poultry manure and this increase could be explained by the fact that this 
fertilizer has a great proportion of nitrogen which could not suppressed pathogen infection. Similar claims were made by [16] who said that the susceptibility of plants to some fungi tends to increase with increased nitrogen supply. According to the same author, nitrogenous fertilizers delay crop maturity by prolonging vegetative development and increasing the risk of infection of plants which are more susceptible to disease at this stage of development. These reports adhere to fluted pumpkins in this study. Furthermore, organic nitrogen sources may allow greater tolerance to vegetative damage because they release nitrogen more slowly retarding the resistance of this plant to attacks. This was true for piggery manure which had a high capacity to retain moisture thus giving a higher humidity and wider canopy to fluted pumpkin, which thus created a good condition for high humidity for the pathogen to established thereby leading to increased disease incidence and severity in the leaflets of the plants. This declaration also supports reports by [19] who said that high humidity is an adequate condition for pathogen establishment. Fluted Pumpkin plants treated with piggery manure were more abundant in the field giving an easy dispersion of fungal spores of $P$. sorghina causing white leaf spot disease which could be disseminated by wind-blown moisture. This conclusion was equally made by [20] who said the denser the plants, the easier the propagation of the spores by wind.

The control experiment had the lowest yield and a higher disease incidence and severity of the three treatments. This is due to the fact that the damages caused by foliar pathogens affect the physiology of the plant. This is in line with the results of [6] who said that foliar diseases affect translocation of photosynthetic products. Also, the fertility of this treatment was lowest insinuating lowest levels of nitrogen, phosphorus and potassium which are typical of friable tropical soils associated with intense leaching and volatilization. The normal physiological processes are hampered by unavailability of nutrients to plants, making the plants to be susceptible to foliar diseases. Interaction of pathogens and the host plants result in rapid penetration and spread which was also subject to environmental influences including soil fertility status. These affirmations are in agreement with the findings of [14]. In this study the greatest significant in disease incidence and severity was recorded in the control treatment which received no input of organic manure of any kind that could boost up its growth and also reduced some stress to disease condition and increased yield [14].

The pathogenicity testing revealed that Phoma sorghina recorded the highest frequency of 18 during isolation, superior to the five other pathogens which confirms that the fact that the pathogen was responsible for the presence of the white leaf spot disease fluted pumpkin in the field. The other pathogens present were opportunistic agents since the plants were already susceptible. These results are similar to the findings of [9] who noted that most pathogens are opportunistic invasive phytopathogens that cause infection when the plants are exposed to danger. The highest frequency of occurrence of $P$. sorghina on fluted pumpkin can be explained that the plant is a specific host to the pathogen and so become more prominent for infection than pathogens. Also, the average temperature of 
the experimental site (Dschang, between $20.4^{\circ} \mathrm{C}-21.8^{\circ} \mathrm{C}$ ) since the optimum temperature for mycelia growth for most fungi is between $20^{\circ} \mathrm{C}$ and $25^{\circ} \mathrm{C}$. These findings were similar with those of [21] who reported that Phoma sp. are ubiquitous in most environments and occupy numerous ecological niches and that the mycelia growth of fungi is favoured by optimum temperature between $20^{\circ} \mathrm{C}$ and $25^{\circ} \mathrm{C}$. Since the Phoma sp. produces spores, the infected spores can easily be disseminated when environmental conditions are favourable which can neither suppressed nor reduced in the field when not managed permitting the evolution of the pathogen. This was in accordance with the results obtained by [22] who said, the inoculum of $P$. sorghina can be suppressed at intervals of two or four weeks if fluted pumpkin is planted at the period when environmental conditions are not favourable for the pathogen.

\section{Conclusion}

Fluted Pumpkin plants were found to be grossly affected by white leaf spot disease which is principally caused by a fungus Phoma sorghina. Moreover, the inorganic manure type used on the plant actually affects the disease. Poultry manure treatment used on fluted pumpkin plants significantly reduced the disease incidence and severity of white leaf spot disease contrarily to piggery manure treatment which instead accentuated the disease condition on the plants. Poultry manure could thus be recommended for the management of white leaf spot disease of fluted pumpkins. Phoma sorghina was reported to be the main pathogen responsible for the white leaf spot disease on fluted pumpkin (Telfairia occidentalis) in the field.

\section{Conflicts of Interest}

The authors declare no conflicts of interest regarding the publication of this paper.

\section{References}

[1] Ndor, E., Dauda, S.N. and Garba, M.N. (2013) Growth and Yield Performances of Fluted Pumpkin (Telfairia occidentalis Hook F.) under Organic and Inorganic Fertilizer on Ultisols of North Central Nigeria. International Journal of Plant and Soil Science, 2, 212-221. https://doi.org/10.9734/IJPSS/2013/3863

[2] Odiaka, N.I., Akoroda, M.O. and Chukwunyem, E.O. (2008) Diversity and Production Methods of Fluted Pumpkin (Telfairia occidentalis Hook F.); Experience with Vegetable Farmers in Makurdi Nigeria. African Journal of Biotechnology, 7, 944-954.

[3] Ayanwale, A.B. and Abiola, M.O. (2008) Efficiency of Fluted Pumpkin under Tropical Conditions. International Journal of Vegetable Science, 13, 35-49. https://doi.org/10.1300/J512v13n03_04

[4] Kayode, A.A.A. and Kayode, O.T. (2011) Some Medicinal Values of Telfairia occidentalis. A Review. American Journal of Biochemistry and Molecular Biology, 1, 30-38. https://doi.org/10.3923/ajbmb.2011.30.38

[5] Jiofack, T., Fokunang, C., Kemeuze, V., Fongnzossie, E., Tsabang, N., Nkuinkeu, R., Mapongmetsem, P.M. and Nkongmeneck, B.A. (2008) Ethnobotany and Phyto- 
pharmacopoea of the South-West Ethnoecological Region of Cameroon. Journal of Medicinal Plants Research, 2, 197-206.

[6] Fayeun, L.S., Alakabe, G.C. and Akinlolu, A.O. (2016) GGE Biplot Analysis of Fluted Pumpkin (Telfairia occidentalis) Landraces Evaluated for Marketable Leaf Yield in Southwest Nigeria. Journal of Saudi Society of Agriculture Sciences, 17, 416-423.

[7] Idris, S. (2011) Compositional Study Telfairia occidentalis Leaves. American Journal of Chemistry, 1, 56-59. https://doi.org/10.5923/j.chemistry.20110102.12

[8] Adenike, K. and Ibronka, I. (2014) Processing of the Fluted Pumpkin Seed as It Affects the Growth Performance and Nutrient Metabolism in Rate. 25 p.

[9] Ashley, B.P., Michelle, M. and Garcia-Diaz, J. (2018) Phoma Infection: Classification, Potential Food Sources, and Their Clinical Impact. Microorganisms, 6, 58. https://doi.org/10.3390/microorganisms6030058

[10] Godwin-Egein, M.I., Okereke, V.C. and Justus, O.P. (2015) Effect of Fluted Pumpkin (Telfairia occidentalis) and Maize (Zea mays) Intercrop on Leaf Spot Disease. American Journal of Agricultural Science, 2, 133-137.

http://www.aascit.org/journal/ajas

[11] Bock, C.H., Gottwald, T.R., Parker, P.E., Cook, A.Z., Ferrandino, F. and Parnell, S. (2009) The Horsfall-Barratt Scale and Severity Estimates of Citrus Canker. European Journal of Plant Pathology, 125, 23-38. https://doi.org/10.1007/s10658-009-9455-x

[12] Barnett, H.L. and Hunter, B.B. (1972) Illustrated Genera of Imperfect Fungi. 3rd Edition, Burgess Publishing Company, Minneapolis, 1-200.

[13] Prasad, R. (2009) Efficient Fertilizer Use: The Key to Food Security and Better Environment. Journal of Tropical Agriculture, 47, 1-17.

[14] Ihejirika, G.O., Nwufo, M.I., Oputa, E., Ogbede, K.O. and Onyia, V.N. (2006) Effect of NPK Fertilizers Rates and Plant Population on Foliar Diseases, Insect Damage and Yield of Groundnut. Journal of Plant Sciences, 1, 362-367.

https://doi.org/10.3923/jps.2006.362.367

[15] Farhad, W., Cheema, M.A., Saleem, M.F., Radovich, T., Abbas, F., Hammad, H.M. and Wahid, M.A. (2013) Yield and Quality Response of Maize Hybrids to Composted Poultry Manure at Three Irrigation Levels. International Journal of Agriculture and Biology, 15, 181-190.

[16] Ekhuemelo, C. and Olatunji, O. (2015) Effect of Soil Amendment on Disease and Yield of Two Pepper Varieties in Makurdi, Benue State, Nigeria. Nigerian Journal of Agriculture, Food and Environment, 11, 75-81.

[17] Djeugap, J.F., Azia, T.A. and Fontem, D.A. (2014) Effect of Compost Quality and Microbial Population Density of Compost on the Suppression of Pythium myriotylum, Causal Agent of Cocoyam (Xanthosoma sagittifolium) Root Rot Disease in Cameroon. International Journal of Sciences. Basic Applied Research, 15, 209-218.

[18] Ahmed, S., Zaman, N. and Khan, S.N. (2012) Evaluation of Manuring Practices on Root Rot Disease and Agronomic Characters of Arachis hypogea L. African Journal of Biotechnology, 11, 1119-1122. https://doi.org/10.5897/AJB11.1342

[19] Venette, R.C. and Cohen, S.D. (2006) Potential Climatic Suitability for Establishment of Phytophthora ramorum within the Contiguous United States. Forest Ecology and Management, 231, 18-26. https://doi.org/10.1016/j.foreco.2006.04.036

[20] Orji, O.J., Ibeawuchi, I.I. and Obilo, O.P. (2015) Effect of Poultry Manure on Incidence and Severity of Foliar Diseases and Weeds of Telfairia occidentalis (Ugu) Intercropped with Cassava and Maize. Journal of Biology, Agriculture and Healthcare, 
5, 2224-3208.

[21] Lin, Z.Y., Wei, J.J., Zhang, M.Q., Xu, S.Q., Guo, Q., Wang, X., Wang, J.H., Chen, B.S., Que, Y.X., Deng, Z.H., Chen, R.K. and Powell, C.A. (2015) Identification and Characterization of a New Fungal Pathogen Causing Twisted Leaf Disease of Sugarcane in China. Plant Disease, 99, 325-332.

https://doi.org/10.1094/PDIS-06-14-0661-RE

[22] Nwufo, M.I. and Ihejirika, G.O. (2008) Influence of Inter-Cropping and Removal of Diseased Leaves on Incidence and Severity of Leaf Spot Disease of Telfairia occidentalis Hook f. Caused by Phoma sorghina. Life Science Journal, 5, 81-83. 